\title{
MODEL PRIORITAS PENANGANAN JALAN (STUDI KASUS DI KABUPATEN TIMOR TENGAH SELATAN, NTT)
}

\author{
Fabianus J. S. Nope' ${ }^{1}$ Ludfi Djakfar ${ }^{2}$, M. Ruslin Anwar ${ }^{3}$
}

\begin{abstract}
Abstrak :
Permasalahan yang dihadapi penyelenggara di Kabupaten Timor Tengah Selatan (TTS) adalah ketidakseimbangan alokasi dana dengan tingkat kerusakan jaringan jalan kabupaten. Realisasi Penanganan jalan di Kabupaten TTS sejak tahun 2011 hingga tahun 2014 terjadi peningkatan panjang jalan pada kondisi baik dan kondisi sedang, untuk kondisi rusak ringan dan rusak berat mengalami penurunan. Tujuan penelitian ini yaitu mengetahui kebutuhan biaya penanganan jaringan jalan, mendapatkan model optimasi biaya penanganan jalan, dan juga mendapatkan urutan prioritas penanganan jalan.

Penelitian ini menggunakan Metode Simpleks untuk menyusun model optimasi biaya penanganan jalan berdasarkan kondisi jalan dan biaya penanganan jalan, Metode Analitic Hierarchy Process (AHP) untuk mengetahui urutan prioritas penanganan jalan. Hasil penelitian menunjukan bahwa total kebutuhan anggaran penanganan jalan tanpa peningkatan lapis permukaan jalan sebesar Rp. 90.097.135.000, penanganan jalan dengan peningkatan lapis permukaan jalan menjadi Lapis penetrasi macadam sebesar Rp. 195.940.825.000. Model optimasi biaya untuk skenario penanganan jalan tanpa peningkatan lapis permukaan jalan adalah $Y=42713,955+499,299 \quad X_{4}$ dimana $X_{4}$ adalah pekerjaan rekonstruksi perkerasan beraspal, sedangkan untuk model optimasi biaya peningkatan lapis permukaan jalan menjadi lapis penetrasi macadam adalah $\mathrm{Y}=46266,005+$ $623,165 \mathrm{X}_{7}$ dengan $\mathrm{X}_{7}$ adalah pekerjaan peningkatan perkerasan tanpa pengikat aspal. Urutan prioritas penanganan jalan dengan metode (AHP) ditinjau berdasarkan persepsi stakeholder's adalah, Ruas jalan dalam kota Soe, ruas jalan oe'oh - Wanibesak, ruas jalan Tumu - Kolbano, ruas jalan Neonmat - Kolbano, ruas jalan Oinlasi - Menu, ruas jalan Oinlasi - Kotolin, ruas jalan Pope - Panite, ruas jalan Sp. Mnelaanen - Fatuatoni, ruas jalan Kaeneno - Nasi, ruas jalan Naususu - Noebesi, ruas jalan Benlutu - Bati, ruas jalan Sp. Kilobesa - Oenino.
\end{abstract}

Kata kunci: Optimasi anggaran, Metode Simpleks, AHP, Kab.Timor Tengah Selatan.

\section{PENDAHULUAN}

Kabupaten Timor Tengah Selatan (TTS) merupakan salah satu kabupaten dalam wilayah Provinsi Nusa Tenggara Timur (NTT). Berdasarkan TTS Dalam Angka 2014, Dinas Pekerjaan Umum (PU) Kabupaten TTS mengelola 1,192,90 km jalan kabupaten, dan sejak tahun 2011 tidak terdapat pembangunan jalan baru, Dinas PU hanya menyelenggarakan pekerjaan pemeliharaan jalan kabupaten.

Kondisi jalan di Kabupaten TTS dalam 3 tahun terakhir dapat dilihat pada Gambar 1. Dari gambar 1 dapat di lihat bahwa terjadi peningkatan kondisi jalan pada kategori baik dan

149

Nope ${ }^{1}$, Adalah Alumnus Program Pascasarjana Jurusan Teknik Sipil, Fakultas Teknik Universitas Brawijaya Malang Djakfar ${ }^{2}$, Anwar ${ }^{3}$, Adalah Dosen Teknik Sipil Fakultas Teknik Universitas Brawijaya Malang 
kategori sedang, namun terjadi penurunan kondisi jalan pada kategori rusak dan rusak berat.

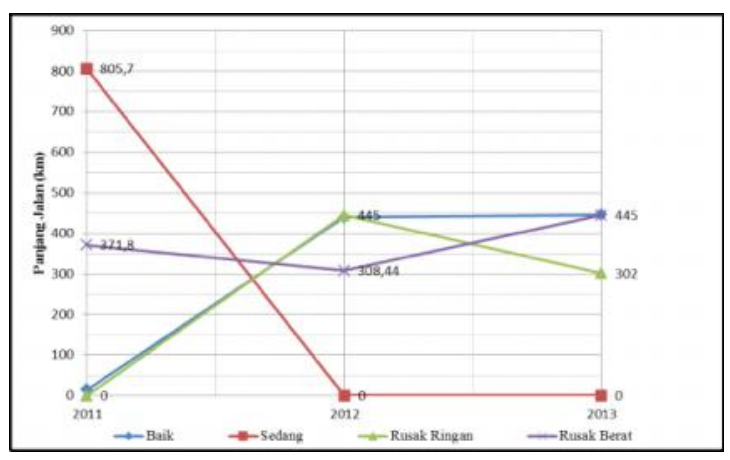

Gambar 1. Kondisi jalan kabupaten di TTS

Menurut Alit Putri (2011), Prioritas penanganan jalan yang dilaksanakan selama ini menyimpang dari prioritas penanganan jalan menurut Surat Keputusan. No.77, Dirjen Bina Marga 1990. Hal ini disebabkan karena kompleksnya permasalahan di lapangan yang dipengaruhi oleh berbagai aspek.

Dari uraian diatas, maka diperlukan suatu kajian dalam mengoptimalkan alokasi dana penanganan jalan dan penetapan urutan prioritas penanganan jaringan jalan di Kabupaten TTS. Adapun tujuan penelitian ini adalah :

1.Mengetahui besarnya total kebutuhan biaya penanganan ruas jalan yang menghubungkan ibu kota Kabupaten dengan ibu kota kecamatan, dan antar ibu kota kecamatan di Kabupaten TTS saat ini.

2.Menyusun model optimasi biaya penanganan jalan, dengan skenario ketersediaan dana eksisting, 5\%, 10\% dari APBD Kab. TTS tahun 2015 dengan metode simpleks.

3. Menyusun alternatif prioritas penanganan jaringan jalan yang menghubungkan ibukota kabupaten dengan ibukota kecamatan, dan antar ibukota kecamatan di Kabupaten TTS dengan metode AHP.

\section{KAJIAN PUSTAKA}

\section{Penelitian Terdahulu}

1.Penentuan Prioritas Pemeliharaan Jalan Kabupaten Berdasarkan Ketersediaan Alokasi Dana, Studi Kasus Jalan Kabupaten Di Kabupaten Tulungagung. (Wahyudiana, 2009) menyatakan penerapan skenario penggunaan alokasi ketersediaan dana yang dimiliki pemerintah daerah sebesar 32,50\%, menunjukan bahwa penilaian dan pembobotan terhadap kriteria mampu menampilkan urutan prioritas yang sesuai dengan kondisi yang ada.

2.Evaluasi kondisi jalan dan pengembangannya, studi kasus di Kecamatan Kepanjen, Kabupaten Malang. (Saputro,2011), menyatakan tipe pemeliharaan yang digunakan pada 16 ruas jalan di Kecamatan Kepanjen dan sekitarnya yaitu: 7 ruas jalan dengan pemeliharaan rutin, 7 ruas jalan dengan pemeliharaan berkala, dan 2 ruas jalan dengan peningkatan jalan.

\section{METODE PENELITIAN}

Metode pengumpulan data dalam kajian ini meliputi data primer dan data sekunder. Data sekunder yang diperoleh dari instansi terkait adalah Data inventarisasi jalan, data pengunaan anggaran pemeliharaan jalan 2 tahun terakhir, RTRW dan RPMJ kabupaten, data harga satuan penanganan jalan saat ini (2015), TTS dalam angka tahun 2014.

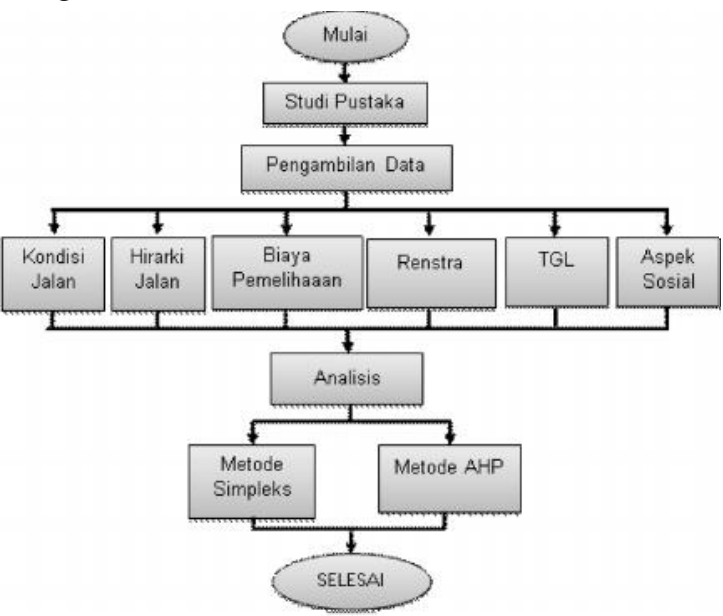

Gambar 2. Karakteristik data dan teknik analisis 
Data primer yang digunakan dalam kajian ini adalah data kondisi jalan penelitian, LHR, dokumentasi dan survai kuisioner metode AHP terhadap 9 stakeholder's dari Bina Marga dan SARPRASKOM (BAPPEDA).

Ruas jalan dalam kajian ini sebagai berikut: Dalam Kota Soe, Neonmat -Kolbano, PopePanite, Tumu - Kolbano, Oinlasi - Kotolin, Oinlasi - Menu, Oe'oh - Wanibesak, Kaeneno - Nasi, Sp. Mnelaanen - Fatuatoni, Sp. Kilobesa - Oenino, Benlutu - Bati, Naususu - Noebesi.

Anggaran pendapatan dan belanja daerah (APBD) Kabupaten Timor Tengah Selatan tahun 2015 sebesar Rp. 1,200,000,000,000,00. Dari total APBD Kabupaten TTS tahun 2015 tersebut Rp. 38,920,623,200.00 atau 3,24\% dialokasikan untuk pemeliharaan jalan kabupaten.

\section{HASIL DAN PEMBAHASAN}

\section{Karakteristik Responden}

Karakteristik responden pada penelitian ini yaitu tingkat pendidikan, jenis kelamin.

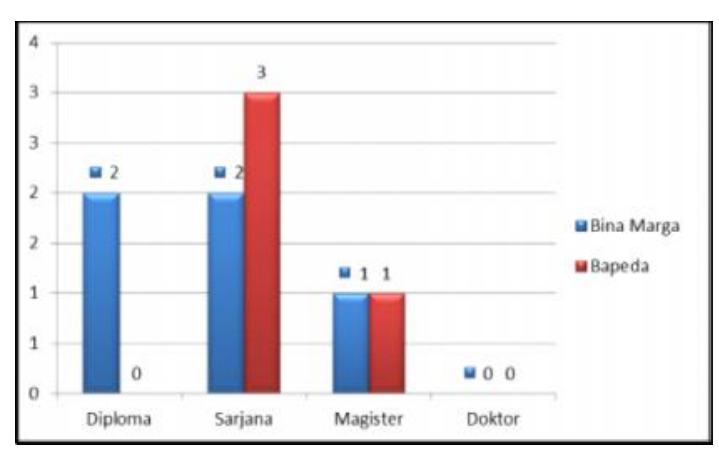

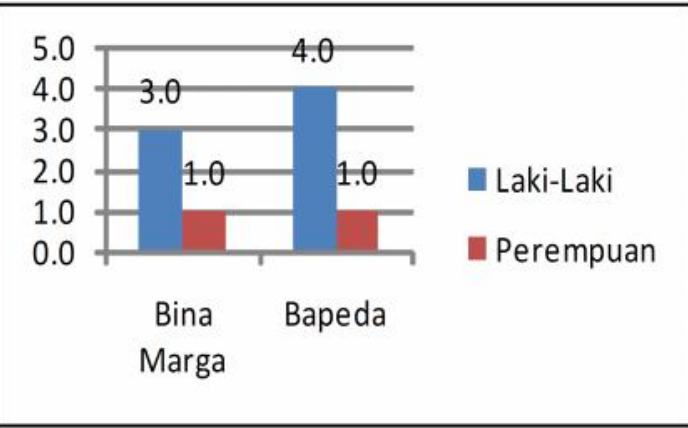

Gambar. 4. Jenis kelamin responden

\section{Uji Validitas dan Reliabilitas Kuesioner}

Berdasarkan hasil uji statistik, kriteria penduduk yang dilayani ruas jalan, nilai $R_{\text {hitung }}$ $<\mathrm{R}_{\text {Tabel}}$, maka variabel jumlah penduduk yang dilayani ruas jalan selanjutnya dinyatakan gugur dan tidak diikutsertakan dalam kuisioner. Nilai Alpha Cronbach 0,850 maka tingkat pengukuran instrumen dapat dikelompokan dalam tingkatan sangat reliabel $(>0,80-1,00)$.

Gambar 3. Tingkat pendidikan responden

Tabel 1. Kondisi jalan

\begin{tabular}{|c|c|c|c|c|c|c|c|c|c|c|c|}
\hline \multirow{3}{*}{ No. } & \multirow{3}{*}{ Ruas Jalan } & \multirow{3}{*}{$\begin{array}{c}\text { Panjang } \\
\text { Jalan } \\
(\mathrm{km})\end{array}$} & \multirow{3}{*}{$\begin{array}{c}\text { Lebar } \\
\text { Jalan } \\
(\mathrm{m})\end{array}$} & \multicolumn{8}{|c|}{ Kondisi Jalan } \\
\hline & & & & \multicolumn{4}{|c|}{ Aspal (km) } & \multicolumn{4}{|c|}{ Tak Beraspal (km) } \\
\hline & & & & B & $\mathrm{s}$ & RR & RB & B & $\mathrm{s}$ & RR & RB \\
\hline 1 & Dalam Kota Soe & 59,87 & 3,5 & 10,44 & 43,02 & 3,13 & 3,28 & & & & \\
\hline 2 & Neonmat -Kolbano & 54 & 3,5 & 1 & 13 & 3 & & 6 & 13 & 12 & 6 \\
\hline 3 & Pope- Panite & 27 & 3,5 & 0 & & & & 5 & 17 & 4 & 1 \\
\hline 4 & Tumu - Kolbano & 32,8 & 3,5 & 0 & 10 & 6 & 12,8 & & & & 4 \\
\hline 5 & Oinlasi - Kotolin & 23,6 & 3,5 & & 5 & 7 & 3 & & & 1,6 & 7 \\
\hline 6 & Oinlasi - Menu & 27,4 & 3,5 & & 5 & 8,4 & 10 & & & 2 & 2 \\
\hline 7 & Oe'oh - Wanibesak & 58,4 & 3,5 & 3 & 13 & 9 & 22,4 & & 3 & 6 & 2 \\
\hline 8 & Kaeneno - Nasi & 19 & 3,5 & & & & & & 4 & 7 & 8 \\
\hline 9 & Sp. Mnelaanen -Fatuatoni & 50 & 3,5 & & & & & & 19 & 21 & 10 \\
\hline 10 & Sp. Kilobesa - Oenino & 15,5 & 3,5 & & & & & & 5 & 10 & 0,5 \\
\hline 11 & Benlutu - Bati & 38,3 & 3,5 & & 4 & & & & 13 & 13,3 & 8 \\
\hline 12 & Naususu - Noebesi & 41 & 3,5 & & 3 & 7 & & & 7 & 19 & 5 \\
\hline & Total & 446,87 & 3,5 & 14,44 & 96,02 & 43,53 & 51,48 & 11,00 & 81,00 & 95,90 & 53,50 \\
\hline
\end{tabular}




\section{Metode Simpleks}

Metode simpleks digunakan untuk menentukan alternatif pemecahan optimasi anggaran pemeliharaan jalan tahunan.

Fungsi tujuan (Z). $Z-14,44 X_{1}-96,02 X_{2}-43,53 X_{3}-51,48 X_{4}-$ $11 X_{5}-81 X_{6}-95,90 X_{7}-53,50 X_{8}=0$

Variabel metode simpleks sebagai berikut:

1. $\mathrm{X}_{1}=\mathrm{PR}$ jalan beraspal $(\mathrm{km})$,

2. $X_{2}=$ PB jalan beraspal $(\mathrm{km})$,

$3 . X_{3}=$ Peningkatan jalan beraspal $(\mathrm{km})$,

4. $X_{4}=$ Rekonstruksi jalan beraspal $(\mathrm{km})$

5. $\mathrm{X}_{5}=\mathrm{PR}$ jalan tidak beraspal $(\mathrm{km})$,

$6 . X_{6}=P B$ jalan tidak beraspal $(\mathrm{km})$,

7. $\mathrm{X}_{7}=$ Peningkatan jalan tidak beraspal $(\mathrm{km})$

$8 . \mathrm{X}_{8}=$ Peningkatan jalan tidak beraspal $(\mathrm{km})$

Analisa penanganan jalan dilakukan dengan dua skenario yaitu penanganan jalan tanpa peningkatan lapis permukaan jalan (ske-nario I) dan analisa penanganan jalan dengan peningkatan lapis permukaan menjadi lapis penetrasi

Tabel 2. Biaya penanganan jalan per kilometer

\begin{tabular}{|c|c|c|c|}
\hline No. & Item Pekerjaan & $\begin{array}{c}\text { Harga Satuan } \\
\text { (Rp) }\end{array}$ & Unit \\
\hline $\begin{array}{l}\text { a. } \\
\text { b. } \\
\text { c. } \\
\text { d. } \\
\text { e. }\end{array}$ & $\begin{array}{l}\text { Pemeliharaan Rutin } \\
\text { (Untuk Jalan Kondisi Baik) } \\
\text { Pembersihan saluran tepi } \\
\text { Perataan Bahu Jalan } \\
\text { Pembersihan Trotoar } \\
\text { Pembersihan Gorong-gorong } \\
\text { Pengendalian tumbuhan/ pemotongan } \\
\text { rumput }\end{array}$ & 7.000 .000 & $\mathrm{~km}$ \\
\hline II. & $\begin{array}{l}\text { Pemeliharaan Berkala } \\
\text { (Untuk Jalan Kondisi Sedang) }\end{array}$ & & \\
\hline a. & Penambalan Lubang Lapen $(5 \mathrm{~cm})$ & 150.000 .000 & $\mathrm{Km}$ \\
\hline b. & Laburan Aspal Pasir (Burda) & 40.500 .000 & $\mathrm{Km}$ \\
\hline $\mathrm{C}$. & Lapis Pondasi Agregat A & 31.500 .000 & $\mathrm{Km}$ \\
\hline III. & $\begin{array}{l}\text { Peningkatan } \\
\text { (Untuk Jalan Kondisi Rusak) }\end{array}$ & & \\
\hline a. & Lapis Penetrasi $(5 \mathrm{~cm})$ & 437.500 .000 & $\mathrm{Km}$ \\
\hline b. & Lapis Pondasi Agregat $\mathrm{A}(15 \mathrm{~cm})$ & 157.500 .000 & $\mathrm{Km}$ \\
\hline c. & Laston (HRS) & 2.450 .000 .000 .000 & $\mathrm{Km}$ \\
\hline IV. & $\begin{array}{l}\text { Rekonstruksi } \\
\text { (Untuk Jalan Kondisi Rusak Berat) }\end{array}$ & & \\
\hline a. & Lapis Penetrasi & 437.500 .000 & $\mathrm{Km}$ \\
\hline b. & Pondasi Telford & 525.000 .000 & $\mathrm{Km}$ \\
\hline c. & Lapis Pondasi (Agregat) B $(20 \mathrm{~cm})$ & 280.000 .000 & $\mathrm{Km}$ \\
\hline
\end{tabular}
macadam (skenario II).

Tabel 3. Batasan biaya penanganan jalan berdasarkan skenario I dan Skenario II.

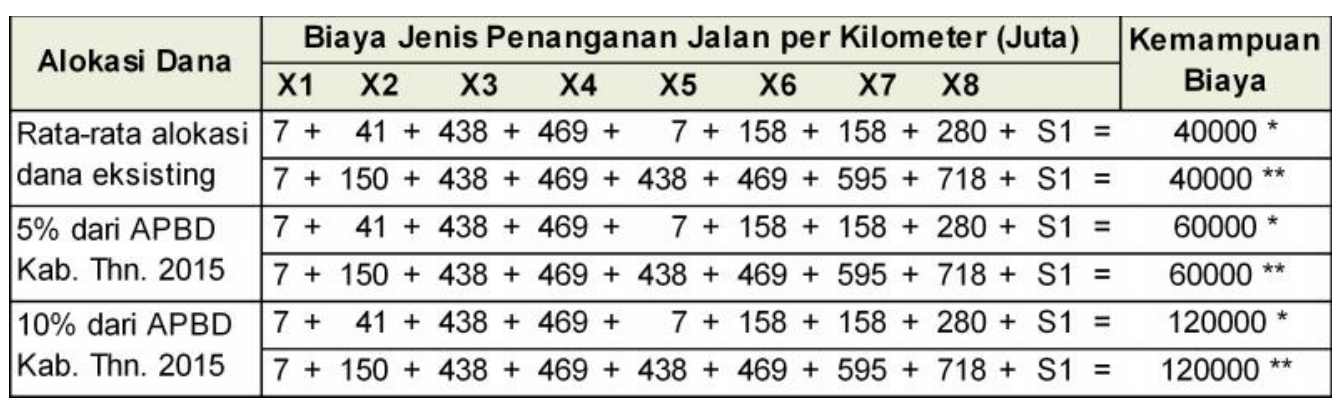

* Skenario I , penanganan jalan tanpa peningkatan lapis permukaan

** Skenario II, penanganan jalan dengan peningkatan permukaan jalan menjadi lapis penetrasi.

Tabel 4. Kendala prioritas penangnan jalan dan batasan jenis pekerjaan jalan

\begin{tabular}{|c|l|l|}
\hline No. & $\begin{array}{l}\text { Batasan prioritas penanganan tanpa peningkatan } \\
\text { permukaan jalan }\end{array}$ & $\begin{array}{l}\text { Peningkatan permukaan jalan dengan lapis } \\
\text { penetrasi }\end{array}$ \\
\hline 1 & $8 X_{1}-7 X_{2}-6 X_{3}-5 X_{4}-4 X_{5}-3 X_{6}-2 X_{7}-X_{8}+S_{2}=446,87$ & $8 X_{1}-7 X_{2}-6 X_{3}-5 X_{4}-4 X_{5}-3 X_{6}-2 X_{7}-X_{8}+S_{2}=446,87$ \\
\hline 2 & $7.000 .000 X_{1}+7.000 .000 X_{5}+S 3=178.000 .000$ & $7.000 .000 X_{1}+S_{3}=101.000 .000$ \\
\hline 3 & $40.500 .000 X_{2}+S 4=3.889 .000$ & $150.000 .000 X_{2}+S_{4}=14.403 .000 .000$ \\
\hline 4 & $469.000 .000 X_{3}+S 5=20.416 .000 .000$ & $437.500 .000 X_{3}+S_{5}=19.044 .000 .000$ \\
\hline 5 & $469.000 .000 X_{4}+S 6=24.144 .000 .000$ & $469.000 .000 X_{4}+S_{6}=24.144 .000 .000$ \\
\hline 6 & $157.500 .000 X_{6}+S 7=12.757 .500 .000$ & $437.500 .000 X_{5}+S_{7}=4.812 .000 .000$ \\
\hline 7 & $157.500 .000 X_{7}+S 8=15.104 .000 .000$ & $469.000 .000 X_{6} S_{8}=37.989 .000 .000$ \\
\hline 8 & $280.000 .000 X_{8}+S 9=14.980 .000 .000$ & $595.000 .000 X_{7}+S_{9}=57.120 .000 .000$ \\
\hline 8 & & $717.500 .000 X_{8}+S_{10}=38.028 .000 .000$ \\
\hline
\end{tabular}




\section{\begin{tabular}{r|l|llll}
$\square$ & 153 & JUTEKS Jurnal Teknik Sipil Volume 2 & Nomor 2 & Oktober 2017
\end{tabular}}

Tabel 5. Tabel awal metode simpleks untuk alokasi dana eksisting skenario I

\begin{tabular}{|c|c|c|c|c|c|c|c|c|c|c|c|c|c|c|c|c|c|c|c|}
\hline $\begin{array}{c}\text { Variabel } \\
\text { Dasar }\end{array}$ & $\mathbf{z}$ & $\mathrm{X} 1$ & $\times 2$ & $\times 3$ & $x 4$ & $\times 5$ & X6 & $\times 7$ & $\mathrm{X8}$ & S1 & S2 & S3 & S4 & S5 & S6 & S7 & S8 & s9 & $\begin{array}{c}\text { Nilai } \\
\text { Kanan }\end{array}$ \\
\hline Z & 1 & -14 & $-96,02$ & $-43,53$ & $-51,48$ & -11 & -81 & $-95,90$ & $-53,5$ & 0 & 0 & 0 & 0 & 0 & 0 & 0 & 0 & 0 & 0 \\
\hline S1 & 0 & 7 & 41 & 438 & 469 & 7 & 158 & 158 & 280 & 1 & 0 & 0 & 0 & 0 & 0 & 0 & 0 & 0 & $40.000,0$ \\
\hline S2 & 0 & 8 & -7 & -6 & -5 & -4 & -3 & -2 & -1 & 0 & 1 & 0 & 0 & 0 & 0 & 0 & 0 & 0 & 446,9 \\
\hline S3 & 0 & 7 & 0 & 0 & 0 & 7 & 0 & 0 & 0 & 0 & 0 & 1 & 0 & 0 & 0 & 0 & 0 & 0 & 178,0 \\
\hline S4 & 0 & 0 & 41 & 0 & 0 & 0 & 0 & 0 & 0 & 0 & 0 & 0 & 1 & 0 & 0 & 0 & 0 & 0 & $3.889,0$ \\
\hline S5 & 0 & 0 & 0 & 469 & 0 & 0 & 0 & 0 & 0 & 0 & 0 & 0 & 0 & 1 & 0 & 0 & 0 & 0 & $20.416,0$ \\
\hline S6 & 0 & 0 & 0 & 0 & 469 & 0 & 0 & 0 & 0 & 0 & 0 & 0 & 0 & 0 & 1 & 0 & 0 & 0 & $24.144,0$ \\
\hline S7 & 0 & 0 & 0 & 0 & 0 & 0 & 158 & 0 & 0 & 0 & 0 & 0 & 0 & 0 & 0 & 1 & 0 & 0 & $12.757,5$ \\
\hline S8 & 0 & 0 & 0 & 0 & 0 & 0 & 0 & 158 & 0 & 0 & 0 & 0 & 0 & 0 & 0 & 0 & 1 & 0 & $15.104,0$ \\
\hline S9 & 0 & 0 & 0 & 0 & 0 & 0 & 0 & 0 & 280 & 0 & 0 & 0 & 0 & 0 & 0 & 0 & 0 & 1 & $14.980,0$ \\
\hline
\end{tabular}

Tabel 6. Hasil optimasi untuk alokasi dana eksisting skenario I

\begin{tabular}{|c|c|c|c|c|c|c|c|c|c|c|c|c|c|c|c|c|c|c|c|}
\hline $\begin{array}{c}\text { Variabel } \\
\text { Dasar }\end{array}$ & Z & $\mathrm{X}_{1}$ & $\times 2$ & $x_{3}$ & $X_{4}$ & $\times 5$ & $x 6$ & $X 7$ & X8 & S1 & $\mathrm{S} 2$ & S3 & S4 & S5 & S6 & S7 & S8 & s9 & $\begin{array}{l}\text { Nilai } \\
\text { Kanan }\end{array}$ \\
\hline $\bar{Z}$ & 1 & 0 & 0 & 40 & 38 & 3 & 0 & 0 & 0 & 0 & 0 & 2 & 2 & 0 & 0 & 0 & 0 & 0 & 26.887 \\
\hline $\mathrm{X8}$ & 0 & 0,03 & 0 & 1,5625 & 1,675 & 0,03 & 0 & 0 & 1 & 0 & 0 & 0 & -0 & 0 & 0 & -0 & -0 & 0 & 29 \\
\hline S2 & 0 & 0 & 0 & -4 & -3 & -12 & 0 & 0 & 0 & 0 & 1 & -1 & 0 & 0 & 0 & 0 & 0 & 0 & 1,379 \\
\hline $\mathrm{X} 1$ & 0 & 1 & 0 & 0 & 0 & 1 & 0 & 0 & 0 & 0 & 0 & 0 & 0 & 0 & 0 & 0 & 0 & 0 & 25 \\
\hline $\mathrm{X} 2$ & 0 & 0 & 1 & 0 & 0 & 0 & 0 & 0 & 0 & 0 & 0 & 0 & 0 & 0 & 0 & 0 & 0 & 0 & 96 \\
\hline S5 & 0 & 0 & 0 & 469 & 0 & 0 & 0 & 0 & 0 & 0 & 0 & 0 & 0 & 1 & 0 & 0 & 0 & 0 & 20.416 \\
\hline S6 & 0 & 0 & 0 & 0 & 469 & 0 & 0 & 0 & 0 & 0 & 0 & 0 & 0 & 0 & 1 & 0 & 0 & 0 & 24.144 \\
\hline X6 & 0 & 0 & 0 & 0 & 0 & 0 & 1 & 0 & 0 & 0 & 0 & 0 & 0 & 0 & 0 & 0 & 0 & 0 & 81 \\
\hline X7 & 0 & 0 & 0 & 0 & 0 & 0 & 0 & 1 & 0 & 0 & 0 & 0 & 0 & 0 & 0 & 0 & 0 & 0 & 96 \\
\hline S9 & 0 & 0 & 0 & -438 & -469 & 0 & 0 & 0 & 0 & -1 & 0 & 1 & 1 & 0 & 0 & 1 & 1 & 1 & 6.909 \\
\hline
\end{tabular}

Tabel 7. Rekapan hasil optimasi anggaran untuk skenario I dan skenario II.

\begin{tabular}{|c|c|c|c|c|c|c|c|c|c|}
\hline \multirow{3}{*}{ Skenario Alokasi Anggaran } & \multicolumn{8}{|c|}{ Panjang penanganan jalan (km) } & \multirow{3}{*}{$\begin{array}{c}\text { Biaya } \\
\text { penanganaan } \\
\text { jalan }(\mathrm{Rp})\end{array}$} \\
\hline & \multicolumn{4}{|c|}{ Perkerasan beraspal } & \multicolumn{4}{|c|}{ Perkerasan tanpa pengikat aspal } & \\
\hline & Rutin & Berkala & Peningkatan & Rekonstruksi & Rutin & Berkala & Peningkatan & Rekonstruksi & \\
\hline \multicolumn{10}{|c|}{ Penanganan jalan tanpa peningkatan struktur permukaan jalan } \\
\hline Eksisting & 25 & 96 & 0 & 0 & 0 & 81 & 96 & 29 & 40.000 .000 .000 \\
\hline 5\% dari APBD Thn. 2015 & 25 & 96 & 0 & 28 & 0 & 81 & 96 & 54 & 60.000 .000 .000 \\
\hline $10 \%$ dari APBD Thn. 2015 & 25 & 96 & 0 & 156 & 81 & 96 & 96 & 54 & 120.000 .000 .000 \\
\hline \multicolumn{10}{|c|}{ Penanganan jalan dengan peningkatan permukaan jalan (Lapen) } \\
\hline Eksisting & 14 & 96 & 0 & 0 & 0 & 54 & 0 & 0 & 40.000 .000 .000 \\
\hline $5 \%$ dari APBD Thn. 2015 & 14 & 96 & 0 & 0 & 0 & 81 & 13 & 0 & 60.000 .000 .000 \\
\hline $10 \%$ dari APBD Thn. 2015 & 14 & 96 & 0 & 0 & 0 & 81 & 113 & 0 & 120.000 .000 .000 \\
\hline 15\% dari APBD Thn. 2015 & 14 & 96 & 0 & 0 & 0 & 81 & 214 & 0 & 180.000 .000 .000 \\
\hline
\end{tabular}

Dari hasil analisa statistik (regresi berganda) diperoleh model optimasi biaya penanganan jalan sebagai berikut:

1.Skenario I,

$$
\mathrm{Y}=42713,955+499,299 \quad \mathrm{X}_{4}
$$

2.Skenario II,

$$
\mathrm{Y}=46266,005+623,165 \quad \mathrm{X}_{7}
$$

\section{Metode Analitic Hierarchy Process (AHP)}

AHP digunakan untuk menganalisa urutan prioritas penanganan jalan dengan memformu- lasikan persentase bobot ruas jalan terhadap bobot setiap kriteria menurut persepsi stakeholder's. Jumlah responden sebanyak 9 responden, dengan rincian 5 responden dari Bina Marga, dan 4 responden dari SARPRASKOM (BAPPEDA). 
Tabel 8. Variabel penelitian untuk metode AHP

\begin{tabular}{|c|c|}
\hline $\begin{array}{c}\text { Variabel } \\
\text { Dependent } \\
\text { (Y) }\end{array}$ & Variabel Independent (X) \\
\hline \multirow{15}{*}{$\begin{array}{c}\text { Urutan } \\
\text { prioritas } \\
\text { penanganan } \\
\text { jalan }\end{array}$} & Faktor Kond is i Jalan \\
\hline & 1. Tingkat kerusakan jalan \\
\hline & 2. Volume LHR \\
\hline & Faktor Hirarki Jalan \\
\hline & $\begin{array}{l}\text { Kelas Jalan, interaksi dengan jalan } \\
\text { propinsi dan jalan nasional }\end{array}$ \\
\hline & Faktor Ekonomi \\
\hline & Biaya pemeliharaan \\
\hline & Faktor Kebijakan \\
\hline & 1. RENSTRA, RTRW kabupaten \\
\hline & 2. Investasi Pemerintah daerah \\
\hline & Faktor Tata Guna Lahan \\
\hline & 1. Pusat Kegiatan Kab. dan Kec. \\
\hline & 2. Kawasan strateg is kab \\
\hline & Faktor Sosial \\
\hline & $\begin{array}{l}\text { Jumlah penduduk yang dilayani } \\
\text { ruas jalan }\end{array}$ \\
\hline
\end{tabular}

Tabel 9. Bobot Hirarki Jalan

\begin{tabular}{|c|l|c|c|}
\hline No. & \multicolumn{1}{|c|}{ Ruas Jalan } & $\begin{array}{c}\text { Nilai } \\
\text { Indeks }\end{array}$ & Bobot \\
\hline 1 & Dalam Kota Soe & 3 & 0,130 \\
\hline 2 & Neonmat -Kolbano & 3 & 0,130 \\
\hline 3 & Pope- Panite & 2 & 0,087 \\
\hline 4 & Tumu - Kolbano & 2 & 0,087 \\
\hline 5 & Oinlasi - Kotolin & 2 & 0,087 \\
\hline 6 & Oinlasi - Menu & 2 & 0,087 \\
\hline 7 & Oe'oh - Wanibesak & 3 & 0,130 \\
\hline 8 & Kaeneno - Nasi & 1 & 0,043 \\
\hline 9 & Sp. Mnelaanen -Fatuatoni & 1 & 0,043 \\
\hline 10 & Sp. Kilobesa - Oenino & 2 & 0,087 \\
\hline 11 & Benlutu - Bati & 1 & 0,043 \\
\hline 12 & Naususu - Noebesi & 1 & 0,043 \\
\hline \multicolumn{2}{|c|}{ TOTAL } & 23 & 1,00 \\
\hline
\end{tabular}

Tabel 10. Bobot LHR

\begin{tabular}{|c|l|c|c|c|}
\hline \multirow{2}{*}{ No. Ruas Jalan } & \multirow{2}{*}{ Ram } & \multicolumn{2}{c|}{ Hari } & \multirow{2}{*}{ Bobot } \\
\cline { 3 - 4 } & & Jam & \\
\hline 1 & Dalam Kota Soe & 199,61 & 2395,30 & 0,23 \\
\hline 2 & Oinlasi - Menu & 94,45 & 1133,35 & 0,11 \\
\hline 3 & Tumu - Kolbano & 78,23 & 938,75 & 0,09 \\
\hline 4 & Oe'oh - Wanibesak & 74,87 & 898,40 & 0,08 \\
\hline 5 & Neonmat -Kolbano & 70,17 & 842,05 & 0,08 \\
\hline 6 & Pope- Panite & 64,38 & 772,60 & 0,07 \\
\hline 7 & Oinlasi - Kotolin & 57,35 & 688,20 & 0,06 \\
\hline 8 & Naususu - Noebesi & 56,77 & 681,25 & 0,06 \\
\hline 9 & Sp. Mnelaanen -Fatuatoni & 56,15 & 673,80 & 0,06 \\
\hline 10 & Benlutu - Bati & 51,06 & 612,75 & 0,06 \\
\hline 11 & Sp. Kilobesa - Oenino & 50,69 & 608,25 & 0,06 \\
\hline 12 & Kaeneno - Nasi & 30,68 & 368,20 & 0,03 \\
\hline \multicolumn{2}{|c|}{ Total } & $\mathbf{8 8 4 , 4 1}$ & $\mathbf{1 0 6 1 2 , 9 0}$ & $\mathbf{1 , 0 0}$ \\
\hline
\end{tabular}

Tabel 11. Bobot kawasan strategis

\begin{tabular}{|c|c|c|c|}
\hline No. & Ruas Jalan & $\begin{array}{c}\text { Nilai } \\
\text { Indeks } \\
\end{array}$ & Bobot \\
\hline 1 & Dalam Kota Soe & 4 & 0,167 \\
\hline 2 & Neonmat-Kolbano & 2 & 0,083 \\
\hline 3 & Pope- Panite & 3 & 0,12 \\
\hline 4 & Tumu - Kolbano & 2 & 0,083 \\
\hline 5 & Oinlasi - Kotolin & 2 & 0,083 \\
\hline 6 & Oinlasi - Menu & 2 & 0,083 \\
\hline 7 & Oe'oh - Wanibesak & 3 & 0,125 \\
\hline 8 & Kaeneno - Nasi & 2 & 0,083 \\
\hline 9 & Sp. Mnelaanen -Fatuaton & 1 & 0,042 \\
\hline 10 & Sp. Kilobesa-Oenino & 1 & 0,042 \\
\hline 11 & Benlutu - Bati & 1 & 0,042 \\
\hline 12 & Naususu - Noebesi & 1 & 0,042 \\
\hline & TOTAL & 24 & 1,00 \\
\hline
\end{tabular}


Tabel 12. Bobot Pusat Kegiatan Kabupaten dan Kecamatan

\begin{tabular}{|c|c|c|c|}
\hline No. & Ruas Jalan & $\begin{array}{c}\text { Nilai } \\
\text { Indeks }\end{array}$ & Bobot \\
\hline 1 & Dalam Kota Soe & 2 & 0,154 \\
\hline 2 & Neonmat -Kolbano & 1 & 0,077 \\
\hline 3 & Pope- Panite & 1 & 0,077 \\
\hline 4 & Tumu - Kolbano & 1 & 0,077 \\
\hline 5 & Oinlasi - Kotolin & 1 & 0,077 \\
\hline 6 & Oinlasi - Menu & 1 & 0,077 \\
\hline 7 & Oe'oh - Wanibesak & 1 & 0,077 \\
\hline 8 & Kaeneno - Nasi & 1 & 0,077 \\
\hline 9 & Sp. Mnelaanen -Fatuatoni & 1 & 0,077 \\
\hline 10 & Sp. Kilobesa - Oenino & 1 & 0,077 \\
\hline 11 & Benlutu - Bati & 1 & 0,077 \\
\hline 12 & Naususu - Noebesi & 1 & 0,077 \\
\hline & TOTAL & 13 & 1,00 \\
\hline
\end{tabular}

\begin{tabular}{|c|l|r|r|}
\hline 5 & Naususu - Noebesi & 8.679 .000 .000 & 0,096 \\
\hline 6 & Neonmat -Kolbano & 7.505 .500 .000 & 0,083 \\
\hline 7 & Benlutu - Bati & 6.544 .250 .000 & 0,073 \\
\hline 8 & Oinlasi - Kotolin & 6.884 .000 .000 & 0,076 \\
\hline 9 & Dalam Kota Soe & 4.723 .085 .000 & 0,052 \\
\hline 10 & Kaeneno - Nasi & 3.972 .500 .000 & 0,044 \\
\hline 11 & Pope- Panite & 3.622 .500 .000 & 0,04 \\
\hline 12 & Sp. Kilobesa - Oenino & 2.502 .500 .000 & 0,028 \\
\hline \multicolumn{2}{|c|}{ Total } & $\mathbf{9 0 . 0 9 7 . 1 3 5 . 0 0 0}$ & $\mathbf{1 , 0 0}$ \\
\hline
\end{tabular}

Untuk mengidentifikasi kriteria yang relevan, maka Metode Cut Off Point digunakan dalam menyeleksi dan memastikan kepentingan kriteria sesuai penilaian seluruh responden. Kriteria yang akan digunakan dalam analisis selanjutnya atau kriteria terpilih adalah kriteria yang memiliki skor lebih dari batas Cut Off Point.

Nilai Cut Off Point $=\frac{\text { Nilai Maks }+ \text { Nilai Min }}{2}$

$$
\begin{aligned}
& =(2,889+2,444) / 2 \\
& =2,667
\end{aligned}
$$

Tabel 13. Biaya penanganan jalan per ruas jalan

\begin{tabular}{|c|l|c|c|} 
No. & \multicolumn{1}{|c|}{ Ruas Jalan } & $\begin{array}{c}\text { Kebutuhan Biaya } \\
\text { Penanganan Jalan } \\
(\text { Rp) }\end{array}$ & Bobot \\
\hline 1 & Oe'oh - Wanibesak & 16.968 .100 .000 & 0,188 \\
\hline 2 & Tumu - Kolbano & 10.153 .200 .000 & 0,113 \\
\hline 3 & Oinlasi - Menu & 9.442 .500 .000 & 0,105 \\
\hline 4 & Sp. Mnelaanen -Fatuatoni & 9.100 .000 .000 & 0,101 \\
\hline
\end{tabular}

Kriteria terpilih berdasarkan hasil analisa Cut Off Point, yang selanjutnya digunakan dalam analisa selanjutnya dalam analisis prioritas penanganan jalan adalah kondisi jalan, hirarki jalan, ekonomi dan tata guna lahan.

\begin{tabular}{|c|c|c|c|c|c|c|c|c|c|c|c|}
\hline \multicolumn{12}{|c|}{ Kriteria Yang Dianalisis } \\
\hline \multirow{2}{*}{ No } & \multirow{2}{*}{ Parameter Penelitian } & \multicolumn{2}{|c|}{ Tidak Penting } & \multicolumn{2}{|c|}{ Penting } & \multicolumn{2}{|c|}{$\begin{array}{l}\text { Sangat } \\
\text { Penting }\end{array}$} & \multirow{2}{*}{$\begin{array}{c}\text { Nilai Skor } \\
\text { Total } \\
\left(3^{\star} 4\right)+\left(5^{*} 6\right) \\
+\left(7^{\star} 8\right)\end{array}$} & \multirow{2}{*}{$\mathbf{n}$} & $\begin{array}{l}\text { Nilai Skor } \\
\text { Rata-rata }\end{array}$ & \multirow{2}{*}{ Ket. } \\
\hline & & $\mathrm{n} 1$ & TP & $\mathrm{n} 2$ & $\mathbf{P}$ & n3 & SP & & & $(9 / 10)$ & \\
\hline 1 & 2 & 3 & 4 & 5 & 6 & 7 & 8 & 9 & 10 & 11 & 12 \\
\hline 1 & Faktor kondisi jalan & 0 & 1 & 1 & 2 & 8 & 3 & 26 & 9 & 2,889 & Batas Atas \\
\hline 2 & Faktor hirarki jalan & 0 & 1 & 3 & 2 & 6 & 3 & 24 & 9 & 2,667 & \\
\hline 3 & Faktor ekonomi & 0 & 1 & 2 & 2 & 7 & 3 & 25 & 9 & 2,778 & \\
\hline 4 & Faktor Kebijakan & 0 & 1 & 5 & 2 & 4 & 3 & 22 & 9 & 2,444 & Batas Bawah \\
\hline 5 & Faktor tata guna lahan & 0 & 1 & 2 & 2 & 7 & 3 & 25 & 9 & 2,778 & \\
\hline 6 & Faktor sosial & 0 & 1 & 4 & 2 & 5 & 3 & 23 & 9 & 2,556 & \\
\hline
\end{tabular}

Tabel 14. Tingkat kepentingan kriteria berdasarkan persepsi responden 
Tabel 15. Hasil pembobotan kriteria stakeholder's

\begin{tabular}{|l|c|c|c|c|c|c|c|c|c|c|}
\hline \multicolumn{1}{|c|}{ Faktor } & SH1 & SH2 & SH3 & SH4 & SH5 & SH6 & SH7 & SH8 & SH9 & $\begin{array}{c}\text { Bobot Rata- } \\
\text { rata }\end{array}$ \\
\hline Tingkat Kerusakan Jalan & 0,09 & 0,11 & 0,16 & 0,18 & 0,20 & 0,04 & 0,11 & 0,13 & 0,14 & 0,1298 \\
\hline Volume LHR & 0,16 & 0,13 & 0,14 & 0,10 & 0,14 & 0,13 & 0,14 & 0,16 & 0,16 & 0,1403 \\
\hline $\begin{array}{l}\text { Kelas Jalan \& Integrasi Dengan } \\
\text { Jn Negara, JIn Prop. }\end{array}$ & 0,19 & 0,16 & 0,14 & 0,16 & 0,16 & 0,20 & 0,16 & 0,13 & 0,16 & 0,1648 \\
\hline Besarnya Biaya Pemeliharaan & 0,16 & 0,16 & 0,24 & 0,23 & 0,20 & 0,22 & 0,20 & 0,16 & 0,14 & 0,1895 \\
\hline Pusat Keg Kab. \& Kec. & 0,19 & 0,23 & 0,16 & 0,16 & 0,16 & 0,20 & 0,20 & 0,13 & 0,16 & 0,1794 \\
\hline Kawasan Strategis Kab. & 0,19 & 0,19 & 0,16 & 0,16 & 0,14 & 0,20 & 0,20 & 0,28 & 0,24 & 0,1961 \\
\hline \multicolumn{1}{|c|}{ Total } & $\mathbf{1 , 0 0}$ & $\mathbf{1 , 0 0}$ & $\mathbf{1 , 0 0}$ & $\mathbf{1 , 0 0}$ & $\mathbf{1 , 0 0}$ & $\mathbf{1 , 0 0}$ & $\mathbf{1 , 0 0}$ & $\mathbf{1 , 0 0}$ & $\mathbf{1 , 0 0}$ & $\mathbf{1 , 0 0}$ \\
\hline
\end{tabular}

Tabel 16. Hasil pembobotan ruas jalan dengan metode AHP

\begin{tabular}{|c|c|c|c|c|c|c|c|c|}
\hline \multirow{2}{*}{ No } & \multirow{2}{*}{ Ruas Jalan } & Kondisi jalan & LHR & Hirarki & Biaya & Pusat keg Kab & Kawasan & \multirow{2}{*}{$\begin{array}{c}\text { Bobot } \\
\text { total }\end{array}$} \\
\hline & & 12,98 & 14,03 & 16,48 & 18,95 & 17,94 & 19,61 & \\
\hline 1 & Dalam Kota Soe & 0,197 & 3,227 & 2,142 & 0,985 & 2,761 & 3,269 & 12,581 \\
\hline 2 & Neonmat -Kolbano & 0,716 & 1,544 & 2,142 & 1,573 & 1,380 & 1,634 & 8,989 \\
\hline 3 & Pope- Panite & 0,341 & 1,263 & 2,142 & 0,758 & 1,380 & 2,451 & 8,336 \\
\hline 4 & Tumu - Kolbano & 1,279 & 1,123 & 1,434 & 2,141 & 1,380 & 1,634 & 8,991 \\
\hline 5 & Oinlasi - Kotolin & 1,450 & 1,123 & 1,434 & 1,440 & 1,380 & 1,634 & 8,461 \\
\hline 6 & Oinlasi - Menu & 1,504 & 0,982 & 1,434 & 1,990 & 1,380 & 1,634 & 8,925 \\
\hline 7 & Oe'oh - Wanibesak & 1,241 & 0,842 & 1,434 & 3,563 & 1,380 & 2,451 & 10,911 \\
\hline 8 & Kaeneno - Nasi & 1,453 & 0,842 & 0,709 & 0,834 & 1,380 & 1,634 & 6,852 \\
\hline 9 & Sp. Mnelaanen -Fatuatoni & 1,141 & 0,842 & 1,434 & 1,914 & 1,380 & 0,817 & 7,528 \\
\hline 10 & Sp. Kilobesa - Oenino & 1,246 & 0,842 & 0,709 & 0,531 & 1,380 & 0,817 & 5,525 \\
\hline 11 & Benlutu - Bati & 1,023 & 0,842 & 0,709 & 1,383 & 1,380 & 0,817 & 6,155 \\
\hline 12 & Naususu - Noebesi & 1,391 & 0,421 & 0,709 & 1,819 & 1,380 & 0,817 & 6,538 \\
\hline
\end{tabular}

Dari hasil pembobotan jawaban responden pada Tabel 15, selanjutnya dilakukan analisis terhadap setiap kriteria pada ruas jalan untuk memperoleh urutan prioritas setiap jalan.

Dari Tabel 16, maka urutan prioritas penanganan jalan adalah Ruas jalan dalam kota Soe, ruas jalan oe'oh - Wanibesak, ruas jalan Oinlasi
- Menu, ruas jalan Tumu - Kolbano, ruas jalan Neonmat - Kolbano, ruas jalan Oinlasi - Kotolin, ruas jalan Pope - Panite, ruas jalan Sp. Mnelaanen - Fatuatoni, ruas jalan Kaeneno Nasi, ruas jalan Naususu - Noebesi, ruas jalan Benlutu - Bati, ruas jalan Sp. Kilobesa Oenino.

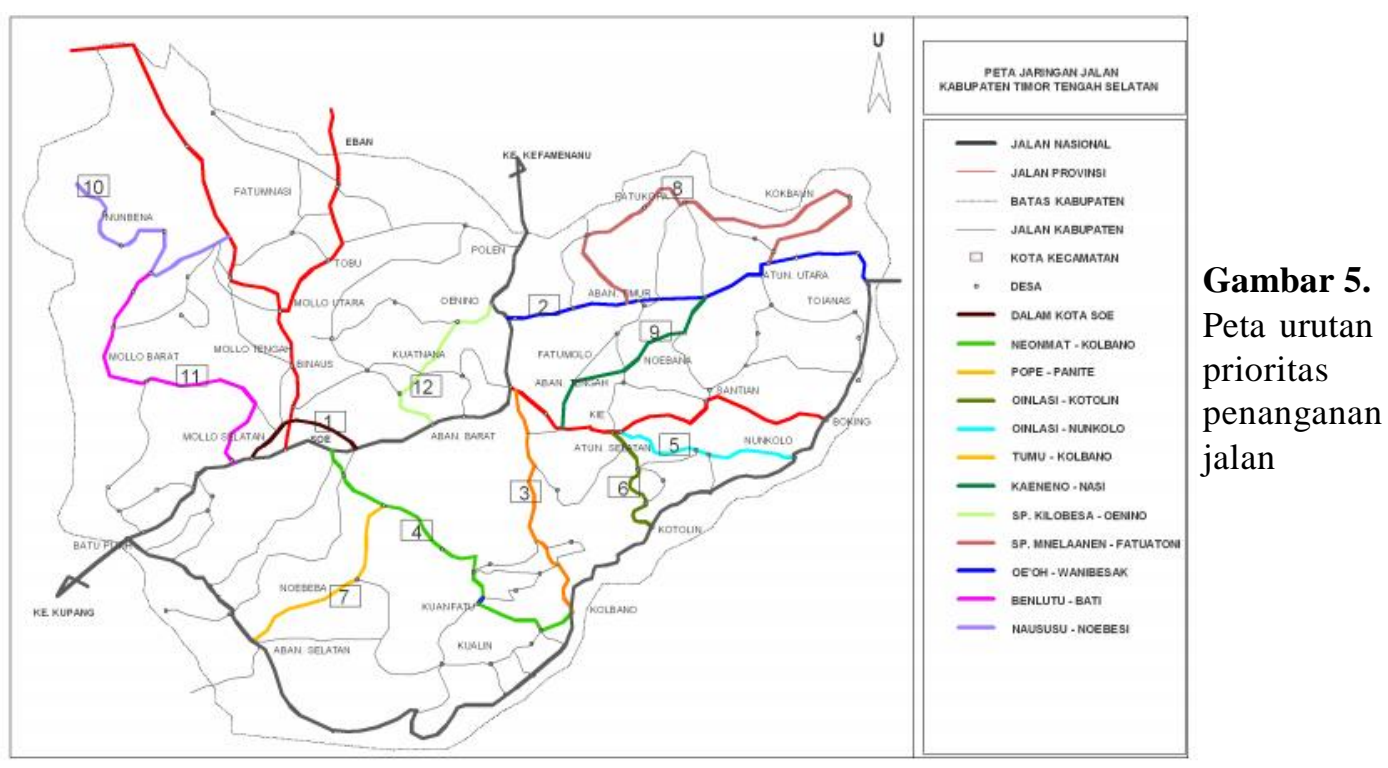




\section{JUTEKS Jurnal Teknik Sipil Volume 2 Nomor 2 Oktober 2017}

\section{KESIMPULAN DAN SARAN}

\subsection{Kesimpulan}

Berdasarkan hasil analisa dan pembahasan yang telah dilakukan maka dapat ditarik kesimpulan penelitian sebagai berikut :

1. Total kebutuhan biaya penanganan jalan tanpa peningkatan jenis permukaan jalan sebesar Rp. 90.097.135.000, total kebutuhan anggaran penangganan jalan dengan peningkatan permukaan jalan menjadi lapen sebesar Rp. 195.940.825.000.

2.Hasil analisa statistik (regresi berganda) diperoleh model optimasi biaya penanganan jalan sebagai berikut:

a.Penanganan jalan tanpa peningkatan permukaan jalan, $\mathrm{Y}=42713,955+499,299 \quad \mathrm{X}_{4}$

b.Penanganan jalan dengan peningkatan permukaan jalan (lapen), $Y=46266,005+623,165 \quad X_{7}$

3. Urutan prioritas penanganan jaringan jalan yang menghubungkan ibukota kabupaten dengan ibukota kecamatan, dan antar ibukota kecamatan di Kabupaten TTS dengan metode (AHP) adalah, Ruas jalan dalam kota Soe, ruas jalan oe'oh - Wanibesak, ruas jalan Tumu Kolbano, ruas jalan Neonmat - Kolbano, ruas jalan Oinlasi - Menu, ruas jalan Oinlasi Kotolin, ruas jalan Pope - Panite, ruas jalan Sp. Mnelaanen - Fatuatoni, ruas jalan Kaeneno - Nasi, ruas jalan Naususu Noebesi, ruas jalan Benlutu - Bati, ruas jalan Sp. Kilobesa - Oenino.

\subsection{Saran}

Penelitian ini belum komprehensif karena hanya mengkaji model prioritas penanganan jalan dari segi kondisi jalan, untuk penelitian selanjutnya disarankan agar mempertimbangkan kriteria kondisi jembatan.

\section{DAFTAR PUSTAKA}

Aminudin. Prinsip-prinsip Riset Operasi. Erlangga. Jakarta. (2005).

Anonim. Bina Marga Kabupaten Timor Tengah Selatan. Harga Satuan Pemeliharaan Jalan. Soe. (2015).

Anonim. Departemen Pekerjaan Umum. Teknik Pengelolaan Jalan, Panduan Pemeliharaan Jalan Kabupaten. (2005).

Anonim. Rencana Tata Ruang Wilayah Kabupaten Timor Tengah Selatan Tahun 2012-2032. BAPPEDA TTS. Soe. (2012).

Anonim. Rencana Pembangunan Jangka Menengah Daerah (RPJMD) Kabupaten Timor Tengah Selatan Tahun 2014-2019. BAPPEDA TTS. Soe. (2014).

Anonim. Timor Tengah Selatan Dalam Angka 2014. Biro Pusat Statistik. SOE. (2014).

Saputro.D.A.dkk. Evaluasi Kondisi Jalan Dan Pengembangan Prioritas Penanganannya (Studi Kasus Di Kecamatan Kepanjen Kabupaten Malang). Universitas Brawijaya. Malang. (2011).

Sudarsana. D.K. Optimalisasi Jumlah Tipe Rumah Yang Akan Dibangun Dengan Metode Simpleks Pada Proyek Pengembangan Perumahan. Universitas Udayana. Denpasar. (2009).

Wahyudiana. Determination Of Regency Road's Maintenance Priority Based On Budget Availability. Universitas Sebelas Maret Surakarta. (2009). 